\title{
METAFORA DAN METONIMI SEBAGAI PEMBENTUK POLISEMI
}

\author{
Munif Yusuf \\ Fakultas Ilmu Pengetahuan Budaya, Universitas Indonesia \\ Pos-el: munifyusuf@yahoo.co.id
}

\begin{abstract}
Abstrak
Salah satu cara untuk mengembangkan kosakata tanpa menciptakan kata baru adalah dengan membuat kata yang sudah ada menjadi polisemi. Penelitian kecil ini bertujuan untuk mengamati peran metafora dan metonimi dalam pembentukan makna kata. Data penelitian ini diambil dari kamus Van Dale Pocketwoordenboek [Nederlands als Tweede Taal] (2003) dan dibatasi pada entri nomina. Penelitian ini dilaksanakan dengan mengamati nomina konkret yang berpolisemi dan menentukan apakah makna baru disebabkan oleh metafora atau metonimi. Acuan yang digunakan dalam penelitian ini adalah Knowles \& Moon (2006) dan Kövecses (2010). Temuan penelitian ini adalah kata bougie 'spark plug', rooster 'jadwal', and tak 'cabang' dibentuk oleh metafora, kata glas 'gelas', doek 'kain' dibentuk oleh metonimi, dan kata apotheek 'apotek' dibentuk oleh metafora dan juga metonimi.
\end{abstract}

Kata kunci: kamus, metafora, metonimi, polisemi.

\begin{abstract}
One of many ways to extend vocabulary without adding new words is by making existed words polysemous. This small research aims to observe the roles of metaphors and metonymies in the formation of words meaning. The data of this research is the dictionary Van Dale Pocketwoordenboek [Nederlands als Tweede Taal] (2003) and it is limited to the noun entries. This research was conducted by observing polysemy on concrete nouns and determining the cause of new meaning whether based on metaphor or metonymy. The main references used to support this research were Knowles \& Moon (2006) and Kövecses (2010). The finding of this research is that the words bougie 'sparks', rooster 'schedule', and tak 'branch' are formed by metaphors and glas 'glass', doek 'cloth' are formed by metonymy. The word apotheek 'pharmacy' is formed by metaphor and metonymy as well.
\end{abstract}

Keywords: dictionary, metaphor, metonymy, polysemy.

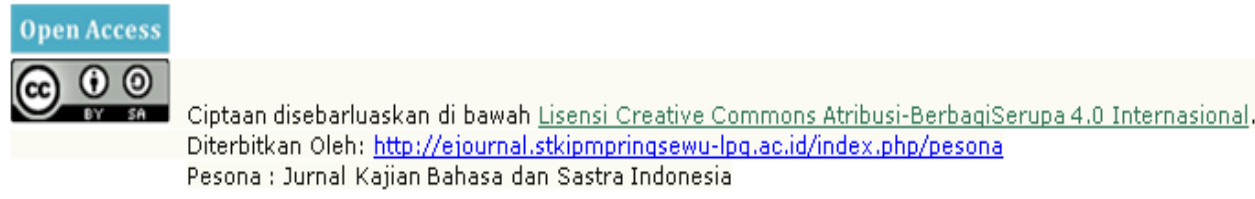




\section{PENDAHULUAN}

Kosakata yang memadai diperlukan sebagai wahana untuk menyampaikan gagasan baik yang sederhana maupun yang majemuk dalam berbagai bidang. Kosakata sehari-hari yang sederhana tidak dapat sepenuhnya menyampaikan gagasan misalnya dalam bidang fisika kuantum, hukum perdata, ekonomi dan moneter, teknologi informasi, dan sebagainya. Oleh karena itu, diperlukanlah pemekaran kosakata sehingga gagasan yang rumit dan majemuk dapat disampaikan dengan baik.

Pemekaran kosakata dapat dilakukan dengan dua cara yakni dengan menggunakan kata-kata dari bahasa lain dan dengan menggali potensi bahasa sendiri. Proses pemekaran kosakata dari bahasa lain biasa disebut penyerapan, borrowing. Di masa lalu, bahasa Indonesia banyak menyerap kata dari bahasa Belanda seperti kamar dari kamer, sepeda dari velocipede, stopkontak dari stopcontact, dan kulkas dari koelkast. Dewasa ini bahasa Indonesia banyak menyerap kata dari bahasa Inggris seperti kata-kata dari bidang komputer dan informatika, misalnya komputer, printer, dan laptop. Selain menyerap kata secara utuh, penyerapan juga dapat dilakukan dengan menerjemahkan istilah dari bahasa lain. Frasa seperti objek penyerta, objek penderita, dan peribahasa tong kosong nyaring bunyinya adalah hasil terjemahan dari bahasa Belanda meewerkend voorwerp, lijdend voorwerp, dan holle vaten klinken het hardst.

Pemekaran kosakata dengan menggali potensi bahasa sendiri dapat dilakukan dengan menciptakan kata baru misalnya petahana sebagai padanan kata incumbent. Menghidupkan kembali kata lama atau arkais yang sudah tidak digunakan dapat pula dilakukan. Kata-kata seperti canggih, kendala, pewara, dan gawai adalah contohnya. Akan tetapi, penciptaan kata monomorfemis baru sulit dilakukan. Terkait dengan itu, Harimurti Kridalaksana (1988: 19) mengatakan:

"Pengungkapan konsep dengan
perpaduan leksem jauh lebih umum
dan lebih mudah daripada dengan
penciptaan leksem tuggal yang baru
sama sekali. Penciptaan leksem
tunggal menuntut daya kreativitas
yang tinggi, dan bila bahasawan
sanggup memunculkan leksem
tersebut, ia masih harus menembus
benteng konvensi yang tinggi dan
tebal supaya ciptaannya itu dapat
dipahami dan diterima oleh
masyarakat bahasa."

Oleh karena itu pemekaran kosakata dapat dilakukan dengan lebih mudah secara morfologis. Dengan afiksasi dihasilkan kata-kata seperti pembelajaran, pemelajar, 
dan dengan komposita atau kata majemuk dapat dihasilkan contoh seperti magnet superkonduktor, percobaan celah-ganda. Kita dapat amati bahwa kata monomorfemis baru jarang ditemukan dan itu berbeda jauh dengan kenyataan bahwa kata bentukan dan komposita dapat dengan mudah kita temukan dalam penggunaan bahasa seharihari.

Cara lain untuk mengembangkan kosakata adalah dengan memberi makna baru pada kata yang sudah ada. Dengan demikian, kata yang ada itu menjadi kata berpolisemi. Dua cara untuk pengembangan makna itu adalah dengan metafora dan metonimi. Kata kepala/hoofd/head adalah contoh pengembangan makna melalui metafora dan metonimi. Kata kepala bermakna 'bagian tubuh di atas leher' (KKBI daring) dan secara metaforis kata kepala/hoofd/head dalam kepala sekolah, schoolhoofd, head of school bermakna 'pimpinan sekolah' dan kata kepala dalam pendapatan per kepala adalah metonimi.

Berdasarkan fakta bahwa metafora dan metonimi adalah cara untuk pengembangan makna, makalah ini akan mengamati bagaimana metafora dan metonimi membentuk polisemi. Tujuan penelitian ini adalah memperlihatkan peran metafora dan metonimi dalam pengembangan makna baik secara kreatif maupun sederhana. Untuk mencapai tujuan itu diperlukan data yang diambil dari kamus Van Dale Pocketwoordenboek [Nederlands als Tweede Taal] (2003) yang dibatasi pada lema nomina. Kamus ini dipilih karena jumlahnya kurang lebih 15.000 lema yang paling sering digunakan. Pembatasan dengan hanya memilih nomina konkret sebagai data penelitian dilakukan karena nomina apa lagi yang konkret lebih sering digunakan dalam penggunaan bahasa seharihari.

\section{Polisemi}

Pengembangan kosakata dengan menambah makna pada kata yang sudah ada mengakibatkan terbentuknya kata berpolisemi. Polisemi adalah kata dengan makna lebih dari satu. Biasanya polisemi dibahas bersamaan dengan homonimi. Hominimi adalah relasi makna yang melibatkan beberapa kata yang kebetulan berbentuk sama. Jika polisemi hanya satu kata, homonimi adalah beberapa kata dengan makna berbeda. Cara yang sederhana untuk melihat apakah suatu kata polisemi atau homonimi adalah dengan melihat kamus. Kata kraken adalah polisemi karena terdiri dari satu lema dengan empat makna dan kata kras adalah homonimi karena terdiri dari dua lema, satu lema berkelas kata nomina dan lema lainnya berkelas kata adjektiva. 
329

\begin{tabular}{|c|c|}
\hline & worden \\
\hline & \\
\hline tigliep, kon je & $\begin{array}{l}\text { tiets } \\
\text { eauto }\end{array}$ \\
\hline n openen [iemand & \\
\hline $\begin{array}{l}3 \text { binnengaan en erin gaan wonen [ie- } \\
\text { mand kraakt een huis]+ toen de school } \\
\text { een jaar leeg stond, heeft een groep men- } \\
\text { sen het gebouw gekraakt }\end{array}$ & $\begin{array}{l}1 \text { krasse oude mensen zij. } \\
\text { leeftijd erg actief en gezo: } \\
\text { + Arend is al } 89 \text { jaar, maa } \\
\text { kras }\end{array}$ \\
\hline $\begin{array}{l}4 \text { met geweld openen [iemand kraakt } \\
\text { een bank, een kluis] } \\
\text { kra.ker [krakers] }\end{array}$ & $\begin{array}{l}2 \text { iets wat kras is, is moeil } \\
=\text { stug }+ \text { en toen heb je me }\end{array}$ \\
\hline
\end{tabular}

Gambar 1

(sumber: Van Dale Pocketwoordenboek, 2003)

Dua pembentuk polisemi yang penting adalah metafora dan metonimi. Dengan metafora dan metonimi kita dapat menambahkan makna dengan mudah dan tanpa kita sadari bahwa kita sebenarnya menggunakan makna metaforis atau pun makna metonimi. Dalam bahasa Inggris kotak surat di kantor-kantor dan sekolahsekolah dikenal sebagai pigeon hole. Pigeon hole secara harfiah adalah kandang burung merpati. Namun, karena bentuknya mirip berupa kotak-kotak - pigeon hole mendapat makna baru berupa makna metaforis sebagai kotak surat. Contoh lain adalah kata sekolah. Makna dasar kata sekolah adalah 'institusi pendidikan'. Akan tetapi, kita dapat membuat kalimat Saya tunggu kamu di sekolah, ya. Kata sekolah dalam kalimat itu mengacu ke 'gedung sekolah'. Dengan demikian, kata sekolah menjadi berpolisemi melalui metonimi.
Metafora

Kita biasanya mengenal metafora dalam kaitannya dengan penggunaan bahasa dalam misalnya ranah susastra, puisi, dan lagu. Metafora juga sering dibahas dalam kerangka gaya bahasa (bahasa Inggris: figure of speech, bahasa Belanda: beeldspraak), misalnya kembang desa yang berarti 'gadis paling cantik dari desa'. Pandangan tradisional sejak zaman Aristoteles menganggap metafora sebagai fenomena susastra yang seharusnya tidak digunakan dalam bahasa sehari-hari. Namun, kenyataannya metafora digunakan dalam berbagai bidang dan itu tanpa kita sadari. Frasa virus komputer, peranti lunak, dan penggelembungan anggaran yang sebenarnya metafora, biasanya tidak dianggap sebagai metafora karena frasa itu tidak digunakan dalam ranah susastra melainkan dalam bidang komputer dan ekonomi.

Metafora didapat dengan membandingkan satu hal dengan hal lain dan antara dua hal tersebut biasanya terdapat kemiripan. Knowles dan Moon (2006) mengatakan bahwa metafora adalah penggunaan bahasa untuk merujuk sesuatu yang lain daripada yang pada awalnya dimaksudkan atau makna harfiahnya dan metafora menyatakan kesamaan atau membuat kaitan antara dua hal. Frasa kaki gunung digunakan untuk menyatakan 
bagian bawah gunung dan itu didapat dengan membandingkan bagian bawah gunung dengan bagian bawah manusia atau hewan yakni kaki. Saat ini - di era kebiasaan baru - jika kita pergi ke supermarket misalnya, sebelum kita diizinkan masuk oleh petugas, ia akan mengukur suhu tubuh kita dengan thermometer gun. Frasa thermometer gun adalah contoh metafora yang didapat dari kemiripan bentuk gun 'pistol' dengan termometer itu. Posisi tangan petugas juga mirip dengan posisi orang yang akan menembak dengan pistol.

Metafora yang dikenal orang biasanya digunakan untuk puisi dan lagu dan berfungsi untuk keindahan berbahasa. Fungsi lain dari metafora yang menjadi sentral tulisan ini adalah metafora sebagai sarana pengembangan kosakata. Dengan menggunakan metafora kita tidak perlu menciptakan kata baru untuk produk baru. Dengan memberi makna baru pada kata itu berdasarkan makna yang sudah ada, maka kita dapatkan metafora untuk produk baru. Setelah sekian lama makna baru itu menempel pada kata, lambat-laun kata itu tidak dirasa lagi sebagai metafora. Kata freelance dalam bahasa Inggris dan bougie dalam bahasa Belanda adalah contohnya. Secara etimologis freelance (free berarti bebas dan lance adalah tombak, lembing) adalah ksatria yang tidak mempunyai lord (tuan) tetap. Ksatria pada abad pertengahan membawa senjata tombak dan sebagai freelance ia bebas mengabdi pada tuan yang ia pilih. Saat ini freelance bermakna pekerjaan yang tidak mengikat. Jika seorang freelancer ingin berhenti bekerja dan berganti pekerjaan, ia dapat melakukannya dengan mudah. Kata bougie berarti lilin penerangan, tetapi saat ini kata itu dikenal dengan makna 'busi'. Makna busi didapat dari perbandingan bentuk dan fungsi bougie. Bougie 'lilin penerangan' berbentuk bulat panjang, ada apinya jika dinyalakan, dan bougie 'busi' juga berbentuk bulat panjang dan menghasilkan percikan api. Dalam bahasa Indonesia kata bunga misalnya juga mempunyai makna metaforis. Makna dasar bunga adalah kembang dan makna metaforisnya adalah 'rente', 'riba'. Jika kita menabung dalam bentuk deposito atau tabungan di bank, maka kita mendapatkan bunga sebagai imbal jasa karena kita telah menempatkan uang kita dalam produk perbankan.

\section{Metonimi}

Metafora biasanya dibahas bersama dengan metonimi. Penggunaan metonimi juga sering dilakukan tanpa disadari bahwa apa yang kita katakan misalnya mengandung metonimi, misalnya kalimat Saya minum tiga gelas. Tentunya yang diminum adalah air atau minuman yang ada di dalam gelas. Metonimi pada kata gelas di 
sini menunjukkan relasi wadah dan isi. Contoh lain adalah penggunaan nama merek sebagai nama produk seperti aqua (bahasa Indonesia) dan spa (bahasa Belanda) untuk air minum kemasan.

Metonimi menggambarkan relasi suatu entitas antara bagian dan keseluruhan atau relasi berdasarkan asosiasi, misalnya the Crown dalam arti 'Monarki', 'Kerajaan', plastic money dalam arti 'kartu kredit'. Metonimi dibangun berdasarkan hubungan kontiguitas, hubungan asosiatif. Hubungan itu adalah hubungan antara vehicle (kendaraan) atau ranah sumber, dengan makna/topic/tenor atau ranah sasaran. Oleh karena itu, Keraf (1994: 142) mendefinisikan metonimi sebagai suatu gaya bahasa yang mempergunakan sebuah kata untuk menyatakan suatu hal lain, karena mempunyai pertalian yang sangat dekat.

Jika metafora secara harfiah tidak benar atau tidak mungkin, metonimi dapat dikatakan sebagian benar (Knowles dan Moon, 2006: 7). Hal itu terkait dengan ranah sumber dan ranah sasaran. Metafora mempunyai dua ranah yang sama sekali berbeda, sedangkan ranah sumber dan ranah sasaran pada metonimi berada dalam bidang yang sama. Dengan demikian, kebenaran sebagian pada aqua dan spa terletak pada kenyataan bahwa keduanya adalah minuman, hanya yang disebut adalah mereknya. Dalam hal ini, minuman dan atribut merek berada dalam bidang yang sama.

Kövecses (2010: 172) menyebut lima kelompok metonimi. Berikut adalah kelima kelompok itu beserta contohnya.

\section{THE PRODUCER FOR THE PRODUCT}

I'm reading Shakespeare.

\section{THE PLACE FOR THE EVENT}

America doesn't want another Pearl

Harbor.

\section{THE PLACE FOR THE INSTITUTION}

Wall street is in a panic.

\section{THE CONTROLLER FOR THE} CONTROLLED

Nixon bombed Hanoi

\section{AN OBJECT USED FOR THE USER.}

The $\operatorname{sax}$ has the flu today

Dari kelima kelompok dan contohnya terlihat bahwa metonimi digunakan untuk mengganti kata lain. Shakespeare, Pearl Harbor, sax digunakan untuk menggantikan karya Shakespeare, peristiwa pemboman di Pearl Harbor, pemain saxofon. Dari contohcontoh itu terlihat bahwa metonimi dapat mengungkapkan sesuatu dengan mudah dan ringkas. 


\section{METODE PENELITIAN}

Metode penelitian ini adalah metode kualitatif. Dengan demikian perhitungan data tidak menjadi hal yang penting dalam penelitian kecil ini. Data diambil dari kamus Van Dale Pocketwoordenboek [Nederlands als Tweede Taal] (selanjutnya disebut kamus NT2) (2003). Kamus ini dipilih untuk menunjukkan polisemi. Selain itu dipilihnya kamus ini karena jumlah lema yang terbatas dan deskripsi makna sederhana. Dari berbagai kelas kata, nomina konkret dipilih untuk membatasi jumlah data yang diteliti. Nomina yang diteliti dibandingkan makna pertama dan makna kedua. Jika polisemi terbentuk melalui metafora atau metonimi, kata itu dicatat untuk dianalisis. Analisis dilakukan dengan membandingkan makna dasar, vehicle atau ranah sumber dan makna metaforis, topic atau ranah sasaran dan relasi antara kedua ranah itu.

\section{HASIL DAN PEMBAHASAN}

Secara garis besar bagian ini terdiri atas dua kelompok, yakni metafora dan metonimi dan karena keterbatasan waktu penelitian, hanya beberapa kata yang dibahas dalam makalah ini.

\section{Metafora}

Lema bougie pada kamus yang diteliti hanya bermakna 'busi'. Akan tetapi, saya mengetahui bahwa kata bougie adalah kata berpolisemi. Oleh karena itu, kata bougie dibahas dalam penelitian ini.

Kata bougie dalam bahasa Belanda pada awalnya berarti 'lilin penerangan'. Kata bougie dengan makna awal ini adalah ranah sumber dan ranah sasarannya adalah 'busi'. Secara metaforis, kata ini menjadi polisemi dengan makna lain yakni 'busi, komponen pada mesin yang berperan dalam pengapian mesin'. Bertambahnya makna bougie karena perbandingan bentuk dan fungsi. Bougie dalam arti 'busi' mempunyai bentuk dan fungsi yang mirip dengan lilin penerangan. Keduanya berbentuk bulat dan panjang dan fungsinya menghasilkan api. Polisemi yang terjadi pada kata bougie ini adalah hasil dari leksikalisasi makna metaforis sehingga makna ini ditambahkan pada leksikon. Makna 'busi' pada bougie adalah contoh dead metaphor (metafora beku), yakni metafora yang telah terkonvensialisasi dan terleksikalisasi sehingga makna metaforisnya tidak terasa lagi.

Kamus NT2 mendaftar lema chip dengan makna 1. een klein schijfje dat een elektronisch apparaat doet werken, bijv. een computer (komponen elektronika); dan 2. een dun gebakken en gezouten schijfje aardappel in een zakje (sejenis kripik). Kamus ini memprioritaskan makna yang lebih populer ditempatkan pada posisi 
pertama. Dengan demikian kamus ini tidak menunjukkan makna yang secara historis lebih tua. Sebenarnya chip dengan makna pertama adalah metafora dari makna kedua. Chip dengan makna kripik secara historis lebih tua sehingga makna itu menjadi ranah sumber dan ranah sasarannya adalah chip sebagai komponen elektronika. Dasar pemetaannya adalah kemiripan bentuk; chip komputer berbentuk kecil dan ringkih dan chip kripik juga demikian.

Lema tak 'cabang' mempunyai dua makna yakni 1. een deel van een boom dat uit de stam of uit een andere tak groeit dan 2. een kleiner deel van een organisatie dat los gaat van het geheel. Makna pertama terkait dengan pohon dan ini menjadi makna dasar, ranah sumber untuk makna kedua yang terkait dengan perusahaan. Makna dasar tak 'cabang' adalah konkret; kita dapat melihat bagaimana bentuk cabang pohon. Perusahaan dapat pula bercabangcabang seperti pohon. Oleh karena itu, makna dasar tak 'cabang' dialihkan dari pohon yang konkret ke perusahaan yang kurang konkret dan itu menjadi dasar terbentuknya polisemi pada kata tak.

Lema rooster memiliki dua makna yakni 1. een soort metalen hekje dat plat ligt en waar iets doorheen kan dan 2. een lijst waarop staat wat er moet gebeuren en wie dat moet doen. Makna pertama adalah 'sejenis pagar logam berjalin renggang' dan makna kedua adalah 'jadwal'. Berikut gambar rooster dengan makna pertama dan kedua.

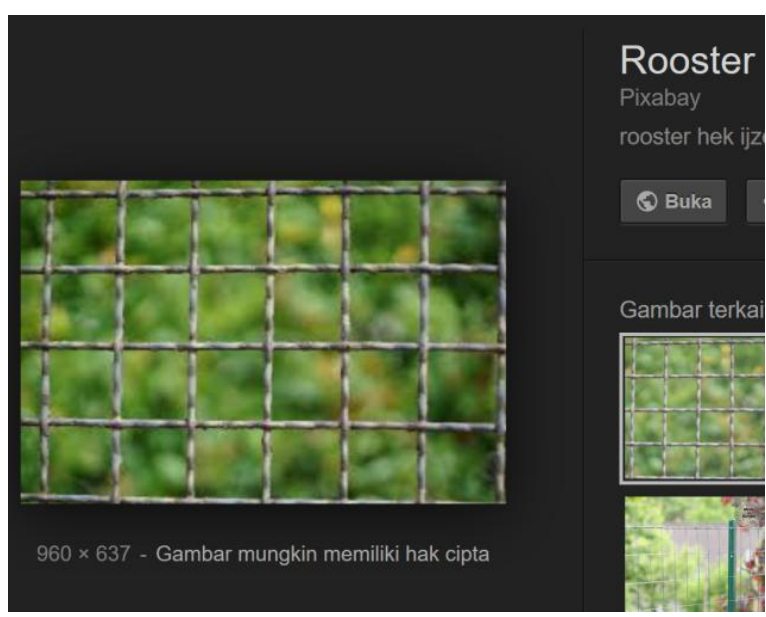

Gambar 2

(rooster, makna pertama),

sumber:

https://www.google.nl/search?biw=1056\&bih=5 01\&tbm=isch\&sa=1\&ei=GjUCW87pDaKW6Q

SKra_IDA\&q=het+rooster+hek\&oq=het+rooste r+hek\&gs_l=img.3...8110.9854.0.10230.4.4.0.0. $0.0 .529 .529 .5-$

1.1.0...0...1c.1.64.img..3.0.0...0.YRyvHODbb

QA\#imgrc $=$ ktnPzCXYPzVG-M:

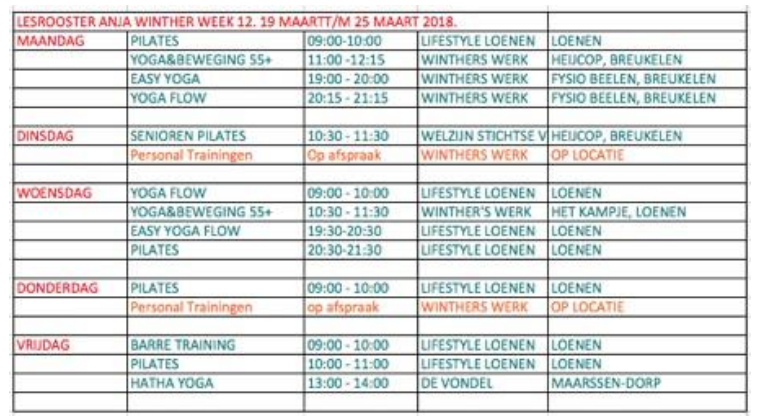

Gambar 3

(rooster, makna kedua), sumber:

http://www.wintherswerk.nl/wintherswerk/Roos ter.html 
Dari gambar dapat dilihat bahwa makna dasar rooster dialihkan ke makna kedua dan kemiripan bentuk, yakni bentuk kotak-kotak seperti pada pagar, menjadi dasar pemindahan makna itu.

Eikel adalah buah pohon eik. Makna dasar ini menjadi ranah sumber yang membentuk makna kedua yang menjadi ranah sasaran dalam relasi metaforis ini, yakni het bovenste deel van de penis (bagian atas/depan penis). Makna kedua dibangun dari kemiripan bentuk buah pohon eik dan bagian depan penis.

Ezel bermakna 'keledai' dalam bahasa Indonesia. Keledai dalam bahasa Belanda dan Indonesia dianggap sebagai hewan yang bodoh. Komponen makna 'bodoh' yang terdapat pada kata ini dialihkan dari hewan keledai ke orang bodoh sehingga dalam bahasa Belanda ezel bermakna iemand die dom is (seseorang yang bodoh). Dengan demikian terjadi peralihan makna dari ranah sumber keledai ke ranah sasaran sasaran orang bodoh.

Metafora yang digunakan dalam ranah susastra biasanya dikenal dengan istilah metafora konvensional. Metafora seperti ini digunakan untuk keindahan kalimat sehingga kita dapat merasakan bahwa kalimat yang dihasilkan adalah kalimat dengan makna figuratif. Dalam penelitian ini tidak ditemukan metafora seperti itu. Metafora yang digunakan dalam kamus adalah dead metaphor atau metafora beku. Metafora ini tidak dirasakan lagi sebagai metafora seperti metafora konvensional. Mungkin di awal penggunaan makna kedua, kata-kata itu dirasakan sebagai metafora seperti metafora konvensional.

\section{Metonimi}

Kata glas dalam kamus NT2 memiliki dua makna, yakni 1. een stof die makkelijk breekt dan 2. een voorwerp van glas (betekenis. 1) om uit te drinken. Makna pertama menjadi ranah sumber bagi makna kedua. Makna pertama kata glas adalah nama bahan dan makna kedua adalah 'benda untuk minum'. Dengan demikian dasar pemetaan makna pertama dan makna kedua adalah NAMA BAHAN ADALAH BENDA.

Kata brons bermakna 1. een metaal van koper en tin dan 2. een rond voorwerp van brons (bet. 1) dat de derde prijs is bij sportwedstrijden. Makna pertama kata brons 'perunggu' menjadi ranah sumber dan makna kedua sebagai ranah sasaran. Kata ini seperti kata glas menunjukkan relasi nama bahan adalah benda. Akan tetapi karena kata brons mengandung atribut tingkat kemenangan (pemenang pertama mendapat emas, kedua perak, dan ketiga perunggu), metonimi yang terbentuk adalah NAMA BAHAN ADALAH TINGKAT KEMENANGAN (JENIS MEDALI). 
Kata doek dalam kamus NT2 memiliki makna 1 . het gordijn dan 2. het schilderij. Kamus NT2 memang tidak menyebutkan bahwa makna doek adalah 'kain'. Akan tetapi, berbagai kamus seperti Van Dale online menyebutkan bahwa makna doek adalah geweven stof (bahan yang ditenun, kain). Makna itu menjadi ranah sumber bagi ranah sasaran het schilderij 'lukisan'. Makna kedua itu terbentuk dari relasi BAHAN ADALAH PRODUK. Hal itu terjadi karena lukisan biasanya dibuat di atas kain.

Kata apotheek sudah lama kita kenal dengan makna yang dan ejaan yang sedikit berbeda, yakni apotek. Lema apotheek dalam kamus NT bermakna 1. een winkel waar je medicijnen kunt halen (toko yang menjual obat) dan 2 de medicijnen die ergens staan (obat yang berada di suatu tempat). Kamus ini juga memberi contoh kalimat ik neem altijd een kleine apotheek mee op vakantie (saya selalu membawa apotek kecil jika pergi liburan). Pada kata apotheek ini terdapat metafora dan metonimi. Secara metaforis, makna dasar 'toko obat' sebagai ranah sumber dialihkan ke ranah sasaran 'obat yang berada di satu tempat'. Metafora konseptual yang dibangun yang menghasilkan makna kedua adalah APOTEK ADALAH OBAT. Kata apotheek adalah metonimi karena apotheek juga bermakna obat, dan obat adalah bagian dari apotek. Dengan demikian relasi yang terbangun dari ranah sumber dan ranah sasaran adalah KESELURUHAN ADALAH BAGIAN.

\section{SIMPULAN}

Metafora dan metonimi adalah cara yang mudah untuk mengembangkan kosakata. Polisemi dibangun dari makna dasar, ranah sumber atau vehicle dan makna metaforis, ranah sasaran atau topic. Vehicle adalah makna pertama dan topic adalah makna hasil pengembangan vehicle. Penelitian ini menggunakan kamus kecil dan itu tidak banyak membantu penelitian polisemi. Penelitian kecil ini menemukan makna dari ranah sasaran adalah metafora dan metonimi konvensional dan tidak menemukan adanya metafora kreatif. Tidak ditemukannya metafora kreatif dapat disebabkan oleh data yang berasal dari kamus kecil. Kamus kecil - apa lagi kamus untuk penutur asing - hanya memuat katakata dan makna yang penting. Terkait dengan penggunaan kamus kecil, kamus NT2 hanya mendaftar satu lema bougie dengan satu makna, yakni 'busi'. Selain itu, kamus NT2 ini juga mendaftar makna berdasarkan makna yang populer dan dibutuhkan, sehingga kata chip direkam dengan makna pertama komponen 
elektronika. Padahal makna pertama kata itu adalah sejenis kripik.

Kamus kecil yang digunakan dalam penelitian ini tidak memiliki makna yang lengkap, sehingga penelitian ini dihentikan di tengah jalan. Oleh karena itu, untuk penelitian sejenis disarankan agar digunakan kamus etimologi, sehingga makna apa yang menjadi ranah sumber dapat diketahui dengan pasti. Walaupun demikian, kamus kecil masih dapat dipakai sejauh digunakan sebagai sumber data dan bukan alat analisis utama.

\section{DAFTAR PUSTAKA}

Harimurti Kridalaksana. (1988). Beberapa Prinsip Perpaduan Leksem dalam Bahasa Indonesia. Yogyakarta: Kanisius.

Keraf, Gorys. (1994). Diksi dan Gaya Bahasa. Jakarta: Gramedia.

Knowles, M. dan R. Moon. (2006). Introducing Metaphor. New York: Routledge.

Kövecses, Z. (2010). Metaphor: A Practical Introduction. Oxford: Oxford University Press.

Moeliono, Anton M. (1989). Kembara Bahasa. Jakarta: Gramedia.

Muhadjir. (2016). Semantik dan Pragmatik. Tangerang: Pustaka Mandiri.

Goded Rambaud, Margarita. (2012). Basic Semantics. Madrid: Universidade Nacional de Educatión a Distancia.
Ritchie, David L. (2013). Metaphor: Key Topics in Semantics and Pragmatics. Cambridge: Cambridge University Press.

Saeed, J.I. (2016). Semantics. Edisi keempat. Oxford: Wiley Blackwell.

Ungerer, F. dan Hans-Jörg Schmid. (2006). An Introduction to Cognitive Linguistics. Edisi kedua. Harlow: Pearson.

Verburg, M. dan R. Stumpel. (2003). Van Dale Pocketwoordenboek Nederlands als Tweede Taal (NT2). Utrecht: Van Dale. 